\title{
Sciendo
}

\section{Reaching the Goal of Alchemy - or: What Happens When You Finally Have Created the Philosophers' Stone?}

\author{
Regula Forster
}

Tübingen University

Wilhelmstraße 113

D-72074 Tübingen, Germany

e-mail: regula.forster@uni-tuebingen.de

\begin{abstract}
:
Alchemy is the art of transforming base metals into precious ones, usually silver and/or gold. The most important method conceived to reach this goal was the creation of the elixir, also called the philosophers' stone, which, applied to the prime-matter, would lead to an accelerated process of ripening of metals, eventually ending in gold. How did Arabo-Islamic alchemists suppose that the transmutation worked? What were the conditions the adept had to fulfil in order to succeed? And what did they think would happen when one finally has created the philosophers' stone? Will the economy collapse because gold and silver will lose their validity? Will the alchemist simply lean back and enjoy? Or will the world end, because man has finally attained the knowledge that should be God's only?

Keywords: Islamicate alchemy, philosophers' stone, transmutation, Ibn Arfa Ra's, eschatology.
\end{abstract}

\section{Introduction}

A definition of alchemy and its goals is not easy to give: Alchemy has been treated as a forerunner of chemistry, as the expression of psychological truths, as a Hermetic tradition, and as a natural philosophy, depending on the inclinations of the scholar studying it (cf. [36, pp. 145-146]). An extremely popular definition is the following one [33, p. 238]:

The ancient study of alchemy is concerned with making the Philosopher's Stone, a legendary substance with astonishing powers. The Stone will transform any metal into pure gold. It also produces the Elixir of Life, which will make the drinker immortal.

Joanne K. Rowling's definition of alchemy, or rather the one on the chocolate frog card, is interesting for several reasons. ${ }^{1}$ While the transmutation of base metals into gold is a generally accepted goal in any alchemical tradition, the creation of an elixir of life is not usually seen as a central element of alchemy. In fact, the idea of an elixir of life seems to be of Chinese origin, while Mediaeval Western (i.e. Arabo-Islamic and medieval and early modern European) alchemy only 
considered the usage of the elixir as extremely efficient medicine that could also prolong one's life, but not lead to immortality. ${ }^{2}$

In this paper, I will discuss the goals of Arabo-Islamic alchemy and the prerequisites that are necessary for the adept and try to find answers to the question of what will happen to the successful adept of the divine art. By doing so, I shall be contextualising Arabo-Islamic alchemy in its contexts as a natural philosophy (see the recent discussion on the occult sciences and their status, especially by Matthew Melvin-Koushki [30] and Liana Saif [34]).

\section{Goals of Alchemy}

As Rowling writes quite correctly in her novel, alchemy is the art of transforming base metals into precious ones, usually silver and/or gold. This holds true also for the Arabo-Islamic world [36, 257]. The creation of a panacea or any kind of substance to prolong one's life, however, is not at the core of Arabo-Islamic alchemy. It may be found in the corpus of writings attributed to Jābir b. Hayyān (fl. perhaps in the second/eighth century) [22, pp. 303-305] (cf. [18, p. 82]; [19, p. 335]; [35, pp. 428-431]; [36, p. 260]), and also occurs in the compendium of the physician Ibn al-Akfānī (d. 749/1348) [38, $\S$ 686-687], but it was never considered very important in the Islamicate world. If we see transmutation as a central element of Arabo-Islamic alchemy, the question remains: how is transmutation to be achieved? Arabo-Islamic alchemical writings describe several methods. The most important or at least most prominent is based on the use of the philosophers' stone ${ }^{3}$ or elixir. For this process, the alchemist must first produce the prime matter and render it passive, that is, "black" and free of accidental qualities. To this prime matter, the stone/elixir - which can be animal, vegetable, or mineral - must be applied. It will then function like yeast in dough, leading to a much accelerated "ripening" of metals, and concluding with the production of gold, or, if incompletely processed, silver. The theory behind this procedure is that all metals are sorts (anwa $)$ of the same species (jins), and therefore they can be transformed into one another. All base metals are subject to a natural process of "ripening" towards becoming silver and gold. Accordingly, the elixir serves only to accelerate this natural ripening process: the alchemist does not create anything out of the ordinary but only expedites the change [5, pp. 104-109]; [36, pp. 257-261].

Alternative methods for achieving transmutation are based on the mercury/sulphur theory [4, pp. 75-79], [18, p. 80], [19, pp. 334-335], [36, pp. 260-261] or the theory of balance ('ilm al-mīzān) [1, pp. 865-867], [4, pp. 94-99], [18, pp. 80-82], [19, p. 335], [36, p. 261]. However, these alternative ideas never gained the prominence of the philosophers' stone, which seems to have become, for many an alchemist, the goal itself, while the transmutation tended to disappear from the picture. As Jābir b. Hayyān explains in the second of the three parts of the Kitāb Ustuquss al-uss ("The Book of the Element of Foundation") [21, p. 84]:

$$
\text { قالو ا فالحجر هو المنى دون ساير الاشياء التى يتو هم ان العمل فيها ومنها }
$$

They say: The stone is what one wishes for, more than all the other things of which one imagines that the work is about or from.

Accordingly, a considerable amount of ink was spent on writing about the philosophers' stone, rather than on other aspects of alchemy. ${ }^{4}$

While making gold is certainly the central goal of alchemy and alchemists, it is clearly not the only one (cf. [32, pp. 207-210]). An interesting example is the seventh/twelfth century Moroccan scholar Ibn Arfa' Ra's who composed a collection of poems, a dīwān, on alchemy entitled Shudhür al-dhahab ("The Splinters of Gold"). ${ }^{5}$ In the first, short poem of the collection, a qașīda in the metre tawīl, he says: ${ }^{6}$
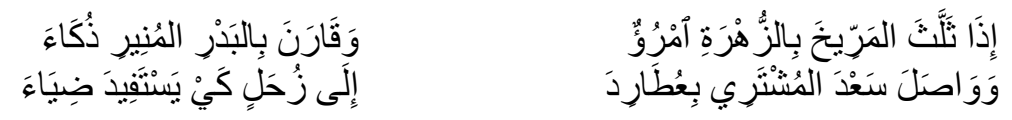

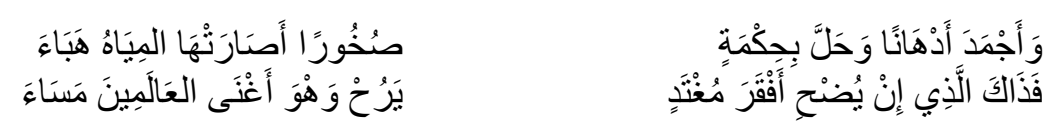

If one triples Mars with Venus,

And unites the sun with the shining full moon

And connects the benefic Jupiter with Mercury

And makes them join Saturn, so that he may gain brightness,

If he makes oils solid and liquefies with wisdom

Rocks that waters have turned into dust,

He will be, even if he was very poor in the morning,

The richest of the worlds in the evening.

The successful alchemist and perhaps the reader of the dīwān by Ibn Arfa 'Ra's will become rich in the end. Even more so, he or she will become the richest of the worlds: Ibn Arfa ' Ra's is not content with this world only, but deliberately speaks of more than one world: 'älamin is usually explained as meaning the worlds of angels, jinn, and mankind, or simply: the universe of created beings [24, vol. 5, p. 2141]. However, in our context, we might ask: Will the successful adept perhaps also be successful in the world to come? Is attaining the transmutation not rather a sign of being chosen by God? We would then have an argument similar to that of Max Weber: being rich is being chosen.

\section{Prerequisites}

Interestingly, texts that discuss the goals of alchemy also rather often speak of the prerequisites the alchemist must have to succeed in the "Great Work". Already in Syriac alchemical writings, authors insist that the real alchemist should not act in order to get rich himself, but that he or she should be ready to sacrifice, live according to religious regulations, be truthful and hardworking [25, vol. 1, p. 77]. Furthermore, he or she should be purified in body and soul, which can be reached by sexual chastity and following strict dietary rules, and he or she should not strive for the creation of gold, but rather for the knowledge about the transmutation. Again, like Harry Potter, who had to want to find the stone, but not for using it in order to get it out of the enchanted mirror [33, p. 217], the ancient alchemist had to strive for knowledge and science rather than for gold and silver. If he or she does so, alchemy will come as a gift of grace from God.

In the Jābirian corpus, the intellectual pre-requisites are stressed. In the first part of the Kitāb Ustuquss al-uss, we read, that the successful alchemist will be "of sound opinion and of necessary analogical reasoning, of continuous studying of the true and obvious science" (dhi l-ra'y al-ṣahịh wa-l-qiyās al-wājib wa-l-dars al-dā'im li-l-ilm al-haqq al-wādihh) [21, p. 71]. If he wants to succeed, he needs, first of all, patience ( $s a b r)$, especially to study the sciences, but then, right after patience, Jābir emphasises the importance of books - or rather: his own books. Only by reading them, will the adept ever be able to perform the great work [21, p. 100]. Finally, purity comes into the picture [21, pp. 109-110]:

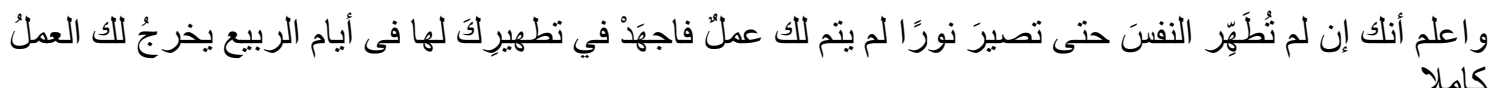

Know: If you do not purify the soul until it becomes a light, no work will become perfect for you. Strive to purify it during the days of spring, and the work will become complete for you.

Alchemy is conditional on a purified soul: It is the adept's soul, rather than his practical abilities, on which the outcome of any alchemical attempt will ultimately depend. 


\section{Eschatology}

If being rich means being rich not only in a monetary, but also - or even more - in a much deeper way, should we not think of alchemy's goal as much more than finding the philosophers' stone and producing gold? And what, then, happens when one finally has created the philosophers' stone?

An otherwise unknown military officer from Upper Egypt, called Hasan Aghā Sirdār, who flourished in the late eleventh/seventeenth century, has two answers (cf. [36, pp. 247-248]; [37, pp. 37-61]). In his treatise entitled Risāla fi l-Hajar al-karim al-makhfí al-zāhir ("Epistle on the precious stone that is both hidden and obvious") he first of all stresses the fact that alchemical knowledge will be granted by God only to the truly pious adept [17, fols. $83 \mathrm{r}-83 \mathrm{v}]$ :

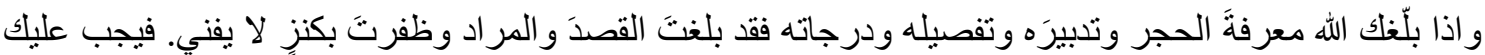

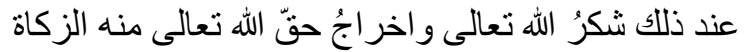

If God were to grant you the knowledge of the stone, its preparation, division and grades, then you would have attained the goal and what you desired and gained a treasure that does not perish. In that case, you must thank God (He is exalted) and do what God (He is exalted) has ordered, especially give alms.

Only the truly pious adept will ever be successful as an alchemist. Once he or she has created the stone, he or she will indeed produce heaps of gold and silver - but only in order to help the poor. The military officer's eschatology is at least partly this-worldly: God's gift, alchemy, will remove poverty.

It cannot come as a surprise that the famous philosopher al-Fārābī (d. 339/950) has a rather different answer to offer. He has written a Maqāla fi wujūb șinā 'at al-kīmiyā' ("Treatise on the necessity of the art of alchemy") in which he explains, that the economy would collapse if making gold were the real goal of alchemy [12, pp. 76-77]:

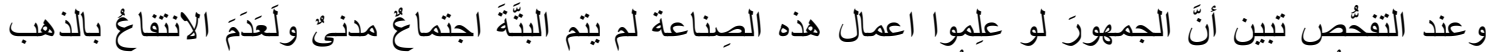

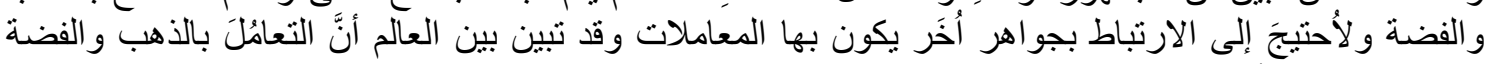

$$
\begin{aligned}
& \text { ضرورئ لا يوجدُ جو هرٌ يُخلفِهما البنَة }
\end{aligned}
$$

When inquiring, it becomes clear that, if the masses knew how to practice this art, a civilised community would definitely not become perfect because gold and silver would not be used advantageously any longer and because one would have to use other substances (jawāhir, also: "metals") for business transactions. In this it is shown for everyone that trade by using gold and silver is necessary. There is absolutely no substance that could replace them.

If alchemy, if the creation of the stone were to become common knowledge, gold and silver would lose their validity as currency and the successful alchemist would not have gained anything. AlFārābī goes on to explain that in fact making gold is not the real goal of alchemy. Rather, the adept trains his mind. Philosophical training and true knowledge are, he goes on to explain, the real goal of the adept [12, p. 77]:

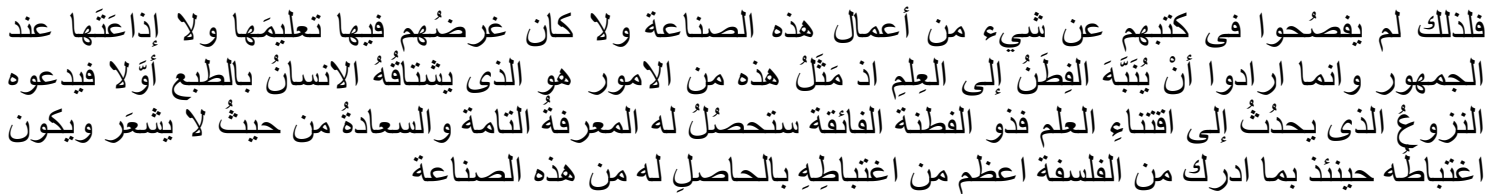

Therefore, they do not express anything of the works of this art clearly in their books, and it is not their goal to teach or spread this [art] among the masses by them (i.e. the 
books). They only want to awaken the intellects for the science, as the like of this [art] are those things that man desires by nature from the beginning. A created longing calls him to acquire this science. The one, who is of superior intellect, will gain perfect knowledge and happiness, without feeling wherefrom, and his joy about his grasp of philosophy will then be greater than his joy about what he gets from this art.

The accomplished alchemist will rejoice in his knowledge - he or she will reach a perfect degree of knowledge and happiness that is above the simple fact of being rich. Al-Fārābī, we might argue, does in fact have an eschatological worldview: The alchemist's goal is perfect knowledge and happiness, a state of mind that might be as well antediluvian and eschatological. However, al-Fārābī does not say what the perfectly trained philosopher will do once he or she has gained this true training of soul and intellect through his study of alchemy.

In the Harry Potter story, the perfect philosopher, the only known owner of the stone, Nicolas Flamel, aged six hundred and sixty six years, agrees to destroy the stone and to die - or, in Professor Dumbledore's words: to go on to the next great adventure. So, is this what will eventually happen to the successful alchemist: a very long life and eventually a self-chosen death?

The Risālat al-Hakìm Qaydarūs ("The epistle of the sage Qaydarūs"), a dialogue probably dating to the second half of the third/ninth or the first half of the fourth/tenth century and therewith more or less contemporary with al-Fārābī, provides us with a kind of answer, although it comes as a sort of by-work, in an explanation by the wise alchemist Mìtāwus. He says [31, §§ 21-22]:

$$
\begin{aligned}
& \text { و الدليلُ على صدقنا فيما ذكرناه أن الحكماءَ لما وصلوا إلى هذا العلم رفَضوا الدنيا وزهَدوا فيها ورغِبوا فى الدار }
\end{aligned}
$$

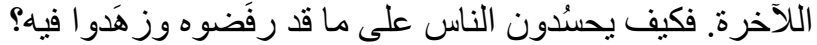

The proof for our truthfulness in what we have mentioned is that the sages have dismissed this world, after they had reached this knowledge, have renounced it [i.e. the

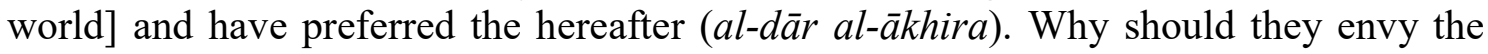
people for something that they have dismissed and renounced?

The alchemical knowledge leads to a complete renunciation of this world and to a desire of the other world, the hereafter. The perfect sage, the real alchemist, will be a perfect ascetic according to this text.

This, in fact, cannot come as a surprise: The close relationship between religion and alchemy has been observed for a long time. As a natural philosophy, alchemy aims at the explanation of the world: alchemy is a "Weltanschauung" that shares concepts of Neo-Platonism and Gnosticism. Seeking gold becomes an equivalent for seeking God. The language and images used by the alchemical authors therefore resemble those of Șüfism and vice versa (cf. [4, pp. 21-22], [23], [36, pp. 149, 196-197, 227]). Furthermore, a special affinity seems to exist between the Shī'a and alchemy (cf. [13], p. 22).

The most explicit reference to the eschatological consequences of finding the stone may be found in the Jābirian corpus of writings and especially in the Kitāb al-Bayān ("Book of the Proof") and the Kitāb al-Ustuquss al-uss studied by Pierre Lory (esp. [27] and [28]). Lory, in several of his contributions on the relationship of alchemy and Süfism and alchemy and Shī ite thought, has offered an explanation of the goal of alchemy and of the eschatology of the adept. In Lory's reading, the transmutation becomes a sign for the fact that the successful alchemist has reached knowledge comparable only to that of the Imām, a knowledge granted by the mercy of God. Knowing how to make the stone means to know all there is to know in the world. The successful alchemist has knowledge equal to that of God - the alchemist will return back to Paradise, where he or she will meet the first Islamic alchemist, Adam (cf. [6, pp. 381, 383-384]). What happens to the world will not be important any longer, as in this reading, what is important is the perfection of the individual, a personal form of eschatology. The imām-cum-alchemist has reached human perfection, and therefore, nothing can touch him anymore. 
In his reading of the Jābirian corpus (or at least of its oldest parts), Lory sees the Jābirian authors as ghulāt, extremist Shī' ites, ${ }^{7}$ who were convinced that the practitioners of alchemy would, by-and-by, become more and more perfect. Lory discerns a connection between the Jābirian writings and the problematic succession of the sixth imām Ja far al-Șādiq. Ja far, we should recall, is said to have been the teacher of Jābir in alchemy and is generally considered an important authority on alchemy especially in Shī' 1 circles (cf. [11], [36, pp. 195-196]). When he died in 148/765, a succession crisis arose (cf. [10]). His son Ismā' 1 l, the designated seventh imām, had died before his father. Some people now thought that Ja far was the last of the imāms, others, that Ismā 'îl was in hiding, yet others thought that the seventh imām was to be seen in Ja 'far's grandson, Muhammad b. Ismā' '̄l, and finally, many opted for one of Ja far's other sons, especially for Mūsā b. Ja'far. When Muhammad b. Ismā'îl died shortly after 179/795-796, the authors of the Jābirian corpus (or at least of parts of it) would have created a new idea to solve the succession problem: not a 'Alid would be the new imām, but the authority of the imām would be transferred to the successful alchemist. Through his alchemical work, the adept would cause the advent of the $q \bar{a}{ }^{\prime} i m$, the awaited mahdī [26, pp. 63-120], [28].

While the connection of at least parts of the Jābirian corpus with the ghulāt seems absolutely convincing, a connection of the Jābirian corpus with the succession of Ja far al-Șādiq poses more problems. This connection seems plausible only in the immediate aftermath of Muhammad $b$. Isma 'îl's death, which would make the Jābirian corpus date from the second/eighth century. While this is consistent with the traditional dating of the corpus and perhaps feasible for its oldest parts, it seems likely that the corpus also contains writings going back to a period quite a bit later than this, dating, as Kraus has argued, to the third/ninth and the first half of the fourth/tenth century. ${ }^{8}$

Notwithstanding these problems, in Lory's reading, the alchemical work becomes the divine wisdom as addressed to mankind. Jābir, accordingly, may expect a special reward on the Day of Judgment, as can be seen in the third part of Kitāb al-Ustuquss al-uss [21, pp. 107-108]. The alchemical work therewith becomes an analogon for the life of man: the last stages of the "work" take place "when the hour comes" (hattā taqūm al-s̄̄'a) [21, p. 110]. And just like the prime matter will, through many-fold distillations, be purified, the adept will also be purified through birth and re-birth: "Every human being dies and comes back similar to himself continuously, until the Day of Judgment" (wa-kullu insānin fa-huwa yatalāshā wa-ya 'ūdu mithluhū dā'iman ilā yawmi l-qiyāma) [21, pp. 99-100].

The alchemical process renewed and reiterated once and again, here is seen as the perfect simile to the life of man. The adept, the accomplished alchemist, is considered the complete, the perfect man, the insān kāmil in an Ibn al- 'Arabī-style terminology, ${ }^{9}$ or the imām in the terms of the Shī‘a.

\section{Conclusion}

Most alchemical texts do not mention what will happen to the alchemist once he or she has created the philosophers' stone. This is in clear contrast to the fact that both the prerequisites for success in the alchemical work and the goals of alchemy are frequently mentioned. By looking at different texts however, we can conclude that while making gold or silver might have been the obvious goals of alchemy, in fact, the deeper or real goal was to acquire a divine knowledge of the functioning of the world. The perfect adept, the successful alchemist, would then not have had a real use for all the gold he or she could, in theory, produce. Rather, he or she would have become a God-seeking and God-fearing ascetic. At the least, the alchemist would start to give away all his or her gold to the poor. Privately however, he or she would live the life of an ascetic and a true God-fearer. Therewith, alchemy becomes nothing more and nothing less than a different form of Șüfism. ${ }^{10}$

\section{Acknowledgment}

I have first presented these ideas at the workshop "Islamic-Eschatology: New Perspectives" (Berlin, Humboldt-Universität, May 2017) and should wish to thank dr. Ghassan El Masri for inviting me 
and all the discussants for their comments. The research for this study was mainly carried out in the frame of the project "Between religion and alchemy" funded by the Swiss National Science Foundation. All translations from the Arabic are mine.

\section{References}

1. Anawati, G. C. Arabic alchemy, In R. Rashed (ed.), Encyclopedia of the History of Arabic Science, London and New York: Routledge, 1996, vol. 3, pp. 853-885.

2. Anthony, S. W. Ghulāt (extremist Shī's̄s), In M. Gaborieau et al. (eds.), Encyclopaedia of Islam, THREE, Leiden: Brill, fasc. 2018-2, 2018, pp. 37-46.

3. Arnaldez, R. al-Insān al-Kāmil, In H. A R. Gibb et al. (eds.), Encyclopaedia of Islam, New Edition, Leiden: Brill, vol. 3, 1971, pp. 1239-1241.

4. Artun, T. Hearts of gold and silver: The production of alchemical knowledge in the early modern Ottoman world, PhD dissertation, Princeton University, 2013.

5. Asatrian, M. Ibn Khaldūn on Magic and the Occult, Iran and the Caucasus, vol. 7, 2003, pp. 73123.

6. Braun, C. "Who Began This Art? From Whence Did It Emerge?": A Hermetic Frame Story on the Origins of Alchemy in Pseudo-Ibn Wahshīya's The Book of the Ziziphus Tree of the Furthest Boundary, al-Qantara 37, 2016, pp. 373-398.

7. Braun, C. and R. Forster. Alchemist und Magier? Ibn Arfa' Ra's (fl. 12. Jh.) im Kontext der arabisch-islamischen Gelehrsamkeit, In J. Eming and V. Wels (eds.), Der Begriff der Magie in Mittelalter und Früher Neuzeit, Wiesbaden: Harrassowitz (forthcoming).

8. de Callataÿ, G. and S. Moureau. Again on Maslama Ibn Qāsim al-Qurțubī, the Ikhwān al-Ṣafā' and Ibn Khaldūn: New evidence from two manuscripts of Rutbat al-hakim, al-Qanțara 37, 2016, pp. 329-372.

9. Carusi, P. Alchimia islamica e religione: la legittimazione difficile di una scienza della natura, Oriente Moderno N. S. 19, 2000, pp. 461-502.

10. Daftary, F. Esmāî̄l b. Ja far al-Ṣādeq, In E. Yarshater (ed.), Encyclopaedia Iranica, Costa Mesa: Mazda Publishers, vol. 8, 1998, 625-626.

11. De Smet, D. Ja far al-Sādeq. iv. And Esoteric sciences, In E. Yarshater (ed.), Encyclopaedia Iranica, New York: Encyclopaedia Iranica Foundation, vol. 14, 2008, pp. 362-363.

12. al-Fārābī and A. Sayili (ed.). Fârârbî'nin Simyanın Lüzûmu hakkındaki Risâlesi, Belleten 15, 1951, pp. 65-79.

13. Forster, R. Alchemy, In M. Gaborieau et al. (eds.), Encyclopaedia of Islam, THREE, Leiden: Brill, fasc. 2016-2, 2016, pp. 15-28.

14. Forster, R. Jābir b. Hayyān, In M. Gaborieau et al. (eds.), Encyclopaedia of Islam, THREE, Leiden: Brill, forthcoming.

15. Forster, R. Wissensvermittlung im Gespräch. Eine Studie zu klassisch-arabischen Dialogen, Leiden and Boston: Brill, 2017.

16. Gardiner, N. Esotericist Reading Communities and the Early Circulation of the Sufi Occultist Aḥmad al-Būnī’s Works, Arabica 64, 2017, pp. 405-441.

17. Hasan Aghā Sirdār. Risāla fì l-Hajar al-karīm al-makhfì al-zāhir, MS Dublin, Chester Beatty Libary, Ar 4025, fols. 80-97.

18. Hill, D.R. Islamic Science and Engineering, Edinburgh: Edinburgh University Press, 1993.

19. Hill, D. R. The literature of Arabic alchemy, In M. J. L. Young, J. D. Latham and R. B. Serjeant (eds.), Religion, Learning and Science in the 'Abbasid Period, Cambridge: Cambridge University Press, 1990, pp. 328-341.

20. Ibn Arfa' Ra's and L. Ghazzali (ed.). Shudhūr al-dhahab, Beirut: Dār al-kutub al-'ilmiyya, 2018.

21. Jābir b. Hayyān and E.J. Holmyard (ed.). The Arabic works of Jābir ibn Hayyān, vol. 1, part 1, Paris: Librairie orientaliste Paul Geuthner, 1928.

22. Jābir b. Hayyān and P. Kraus (ed.). Mukhtār rasā'il, Paris: Maisonneuve, 1935. 
23. Johnson, K. V. Jalāl al-Dīn Rūmī’s Use of Alchemical Imagery, Islamic Culture 70, 1996, pp. $1-25$.

24. Lane, E. W. An Arabic-English Lexicon, 8 vols., London: Williams and Norgate, 1863-1893.

25. von Lippmann, E. O. Entstehung und Ausbreitung der Alchemie, 3 vols., Berlin: Springer, 1919-1954.

26. Lory, P. Alchimie et mystique en terre d'Islam, [Paris]: Verdier, 1989.

27. Lory, P. Aspects de l'ésotérisme chiite dans le Corpus Ğābirien. Les trois Livres de l'Elément de fondation, al-Qantara 37, 2016, pp. 279-298.

28. Lory, P. Eschatologie alchimique chez Jâbir b. Hayyân, Revue des mondes musulmans et de la Méditerranée, vols. 91-94, 2000, pp. 73-92.

29. Masāḥ, R. Ibn Naqarāt, In Dā'irat ul-ma 'ārif-i buzurg-i islāmī, vol. 5, 1993, pp. 57-58.

30. Melvin-Koushki, M. Introduction: De-orienting the Study of Islamicate Occultism, Arabica 64, 2017, pp. 287-295.

31. Müller, J. Zwei arabische Dialoge zur Alchemie. Die Unterredung des Aristoteles mit dem Inder Yūhīn und das Lehrgespräch der Alchemisten Qaydarūs und Mītāwus mit dem König Marqūnus. Edition, Übersetzung, Kommentar, Berlin: Klaus Schwarz, 2012.

32. Principe, L. M. The secrets of alchemy, Chicago: University of Chicago Press, 2013.

33. Rowling, J. K. Harry Potter and the Philosopher's Stone, London: Bloomsbury, 1997.

34. Saif, L. From $\dot{G} \bar{a} y a t$ al-hakìm to Šams al-ma'ârif: Ways of Knowing and Paths of Power in Medieval Islam, Arabica 64, 2017, pp. 297-345.

35. Strohmaier, G. Elixir, alchemy and the metamorphoses of two synonyms, al-Qantara 37, 2016, pp. 423-434.

36. Ullmann, M. Die Natur- und Geheimwissenschaften im Islam, Leiden: Brill, 1972.

37. Ullmann, M. Katalog der arabischen alchemistischen Handschriften der Chester Beatty Library, 2 vols., Wiesbaden: Otto Harrassowitz, 1974-1976.

38. Witkam, J. J. De egyptische arts Ibn al-Akfān̄̄ (gest. 749/1348) en zijn indeling van de wetenschappen. Editie van het Kitāb iršād al-qāṣ̦id ilā asnā al-maqāṣ̦id, Leiden: Ter Lugt Press, 1989.

\section{Notes}

1. It should be noted that the book, while published as Harry Potter and the philosopher's stone in Great Britain, is entitled Harry Potter and the sorcerer's stone in the US-American version. Although this title obscures the alchemical aspect (cf. [32, p. 1]), we could read it as emphasising the connections between alchemy and magic which definitely exist (on these see [7], [9] and [36, p. 145]).

2. [32, p. 5]. On the medical aspects typical for Late Medieval European alchemy see [32, esp. pp. 71-72], with reference to John of Rupescissa, while a connection of the fifteenth century French alchemist Nicolas Flamel with the "elixir of life" as suggested in Rowling's novel seems to be an eighteenth-century invention (cf. [32, p. 227, n. 56]).

3. I prefer the term "philosophers' stone" to the more-commonly used "philosopher's stone" (also used in the Harry Potter series), as it translates nicely the Arabic terms hajar al-falassifa ("stone of the philosophers") and hajar alhukamā" ("stone of the sages"). On the Arabic terms of the stone or elixir see [36, pp. 257-258].

4. A work on the preparation of the philosophers' stone, Kitāb Tadbīr al-hajar al-mukarram ("Book on the preparation of the honoured stone"), has been attributed to the mystic Junayd (d. 298/910, cf. [36, p. 197]). The stone is also at the centre of a pseud-epigraphic dialogue between Aristotle and the Indian sage Yūhīn (perhaps third/ninth or fourth/tenth century; ed. [31, pp. 13-26]; cf. [15, s. index]) and of Agathodaimon's death-bed talk to his pupils, Risālat al-hadhar ("Epistle of Warning", perhaps third/ninth or fourth/tenth century; cf. [15, s. index]). A later example would be 'Alī Bek al-Iznīqī's (also known as al-mu'allif al-jadīd, "the new author", ninth/fifteenth or tenth/sixteenth century) Risālat alDurra al-bayd̄̄ 'wa-l-yāqūt al-hamrā" ("Epistle of the white pearl and the read ruby", cf. [36, p. 244]).

5. Ibn Arfa ' $\mathrm{Ra}$ 's is traditionally identified with a Mālikī scholar called Ibn al-Naqirāt. However, this identification has been questioned tentatively by Masāh [29]. Juliane Müller (Zurich) and the present writer are challenging the commonly accepted traditional identification in a forthcoming article on "The Identity, Life, and Works of the Alchemist Ibn Arfa' Ra's" (submitted to al-Qantara).

6. I cite the text established by Svetlana Dolgusheva (Zurich), who is currently preparing a critical edition of Shudhür al-dhahab, based on MS Istanbul, Istanbul, Topkap1, A. 2572 as "Leithandschrift". The edition by Lahouari Ghazzali [20] who uses manuscripts from Leipzig, Tehran, and the Escorial, gives a slightly different text. - The translation is mine; based on work by all members of the Zurich team (Christopher Braun, Svetlana Dolgusheva, and Juliane Müller).

7. On the ghulät, see for example [2]. 
8. On the dating of the Jābirian corpus and the research debate around it see [14]. In his presentation on "The Historicity of Jābir ibn Hayyān: An overview of the external sources" at the Gotha manuscript workshop "Alchemy in the Islamicate world" (28-29 September 2018), Thijs Delva has argued that the corpus, even its later parts, was known to Maslama b. Qāsim al-Qurțub̄i, the author of Ghāyat al-ḥakim ("The goal of the sage") and Rutbat al-hakìm ("The station of the sage"), already before his return to the Islamicate west. As he returned to al-Andalus in 325/936 (cf. [8, p. 336]), this would be a rather early and so far ignored terminus ante quem for the completion of the Jābirian corpus.

9. On the concept of the "perfect man" see [3].

10. This would be in keeping with a kind of Șūfì reorientation of the occult sciences that has been argued for by Gardiner [16] and Saif [34]. 